\title{
ANTHROPOLOGIC MISCELLANEA
}

Recent Work of the Wisconsin Archeological Society. - The bill to promote the work of the Wisconsin Archeological Society, introduced in the Wisconsin legislature early in February last and previously mentioned in these pages (American Anthropologist, vol. 7, 1905, p. 170), received the unanimous support of that body and became a law by approval of the Governor on June ro. This enactment, which is the first that has ever been made in the interest of Wisconsin archeology, provides for the printing, at the expense of the State, of $I, 500$ copies of the bimonthly Transactions of the Wisconsin Archeological Society in pamphlet form, not to exceed 75 pages per number, with the necessary illustrations. Of this edition several hundred copies will be presented to the Wisconsin Free Library Commission for distribution among its traveling libraries. These Transactions will supersede the Bulletin that has been published quarterly by the Society under the editorship of Mr Charles E. Brown. One of the first numbers of the Transactions that will be published under the new law will consist of a monograph on the Aboriginal Pipes of Wisconsin, by the president of the Society, Mr George A. West, who has devoted many years to a study of the subject and the collection of material relating thereto. This noteworthy collection, comprising many hundreds of specimens, representing every period and type from the primitive pebble and tube pipes to the clay, lead, and iron pipes of early historic times, will eventually be presented to some worthy institution. It is also proposed to publish catalogues of archeologic collections from Wisconsin, and to this end a beginning has been made toward listing all collections of the sort now deposited in large museums outside the State. This is a laudable enterprise, as it will make available to students of Wisconsin archeology all scattered material pertaining to the subject.

Research work under the auspices of the Society is being conducted in many parts of the State by a larger number of trained students than ever before. Mr Charles E. Brown, secretary and curator, now devotes his entire energy to the work of the Society. During the present season Mr Brown will conduct a small party in the field with the view of completing the location and survey of the aboriginal monuments and eventually of effecting their preservation, and for the purpose of obtaining notes, photographs, maps, and artifacts. Headquarters for the Society have been 
opened at Milwaukee, where a bureau of records is established and whence members throughout the State will be directed in their researches. The State Board of Agriculture has become interested in the Society's endeavors, and is furthering its plans for lectures and the exhibition of collections, photographs, charts, maps, and models of the archeologic features of various sections of Wisconsin, at the forthcoming State Fair at West Allis, where, it is hoped, interest in the work will be greatly increased, particularly as a group of mounds, preserved through the efforts of the Society, is situated within the limits of the fair grounds, forming an object lesson in the preservation of local antiquities.

One of the purposes of the Society, in which it has been especially successful, has been to induce the owners of fugitive specimens, as well as of large collections, to present them to or to place them on deposit in some local museum or educational institution; and in some instances the Society has purchased collections for this purpose. No effort has yet been made to concentrate the collections of Wisconsin in a great central museum, so that while journeys of considerable length are necessary in order to examine representative collections of Wisconsin artifacts, the plan has the advantage of arousing local interest in archeology in many communities, and ultimately will stimulate effort in many directions toward advancing the Society': project for the preservation of antiquities.

The growing interest in archeology is manifest throughout Wisconsin. For several years a course in American history and archeology has been given by Dr George L. Collie, of Beloit College, to which Mr Frank A. Logan, of Chicago, generously presented the Rust collection at the close of the Columbian Exposition in 1893, and to which he has recently added the W. H. Elkey collection of 6,000 stone and copper implements. The Oshkosh Public Library, through the efforts of the Wisconsin Society, has become one of the repositories of Wisconsin archeological material, and in addition has recently received the James G. Pickett collection, from the Lake Winnebago region, through the liberality of Mrs Leander Choate. The Kellogg Library at Greenbay is another repository, having recently received on deposit the collection of J. P. Schumacher, a member of the Wisconsin Society. These objects were gathered from the vicinity of Greenbay. The collection of the late $I$. A. Lapham, well known through his researches in Wisconsin archeology and history, and the J. A. Rice collection of Mexican antiquities, will shortly be presented by the Wisconsion Archeological Society to the Milwaukee-Downer College. It is thus seen that the Society's efforts in placing private collections where they will be accessible to students and open to view by every one, have met with gratifying success. 
A project is afoot to prevent the counterfeiting of Wisconsin specimens and to prohibit artifacts from being taken from the State for commercial purposes. In this endeavor every one will wish the Society success, since its officers assure us that the plans will not hinder the acquirement of Wisconsin collections by the great museums of the country or of the world, recognizing the fact that archeology cannot be limited by political boundaries nor the interests of science advanced by illiberality. As the work of the Archeological Society develops, and the collections within the State become better known and catalogued, it will be found, no doubt, that the collections of even the great museums of the country may be greatly enriched by exchange for the Society's duplicates.

HARI.AN I. SMITH.

Explorations at Cavetown, Maryland. - In May, 1905, explorations were carried on by Phillips Academy of Andover, Mass., at Cavetown, Washington county, Maryland, in a cave controlled by Mr G. M. Bushey. His son, Mr F. E. Bushey, was much interested in the spot, and it was largely through his representations that the work was attempted. Previous excavations had been made by Mr Joseph D. McGuire, of Washington, and by others. The cave is in a limestone formation to the west of the Blue Ridge mountains, itself facing east from a ridge running parallel to the rnain ridge of the mountains. The opening, resembling that of an ordinary rock shelter, is about $2 \mathrm{I}$ meters wide and leads to a chamber of which the front part is about 16 meters deep. In this most of the explorations were carried on. Farther under the hill the cave runs westward for about two hundred meters, ending in a small pool. Pits were sunk and trenches dug in the hope of finding traces of early man, but nothing suggestive of great age was found. Stone and bone implements in moderate profusion existed, also numerous animal bones. Along the north wall of the chamber, as well as elsewhere, stalagmitic formations containing a sort of charcoal-bone breccia were discovered and specimens taken. At the back of the chamber a hard stalagmitic floor had formed, and under this was a deposit of red cave earth. In this were no traces of man's occupancy, but in a similar deposit in a quarry outside the cave were found many fossilized animal bones; the identification of these will determine the paleontological character of the red-earth stratum, in which, if anywhere, future excavations are likely to lead to the discovery of traces of the early " cave man" of European reputation. The research was greatly aided by the work and advice of Prof. William H. Holmes of the Bureau of American Ethnology, and of 
Mr McGuire whose previous work made his coöperation, freely extended. 
Gran Quivira. - A conspicuous example of the alienation of important archeological sites through the operation of the homestead laws is that of Tabira, popularly known as "Gran Quivira," in eastern Socorro county, New Mexico. A homestead entry was filed some years ago on the quarter-section of land upon which are situated the ruins of this pueblo. This wis the most extensive of the Piro settlements and is the best preserved $c_{2}$ all the Piro ruins. Its situation on the eastern frontier of the Pueblo region renders it of unusual importance. No collections of any importance have been made from the ruins of that region. After a long contest this homestead has recently been declared valid and a patent issued to the claimant.

Pajarito Park.-By executive order of July 29, 19०5, an additional reservation of about 33,000 acres has been given to the Santa Clara Indians. This extension embraces all of the great Puye or Santa Clara group of cliffdwellings, the principal center of interest in the proposed Pajarito $\mathrm{Na}$ tional Park. There can be no question as to the justice of this extension. It is merely giving the Indians a part of what already belonged to them by virtue of the grant of 90,000 acres by the crown of Spain to the Santa Clara pueblo in 1727 , which was confirmed by Governor General Cachupin in his decree of $r_{7} 63$. The restitution of even a part of this land to the Indians must be commended. It is to be regretted, however, that the Indians were not offered in lieu of the few sections containing the most important ruins, other lands equally valuable for timber and grazing, and this great group of prehistoric ruins, which many travelers have asserted would be the most attractive of all our national parks, held by the Government for the benefit of the public. As it is, the national park proposition will probably be abandoned. The Indian Office will provide for the preservation of the ruins. Fortunately the other groups of ruins of the Pajarito plateau are brought within the recently proclaimed Jemez Forest Reserve, so that their protection and preservation are assured.

Edgar L. HewetT.

Supposed Shoshoneans in Lower California. - The peninsula of Lower California has been regarded by some to have been helu in its entirety, and by everyone over at least its whole northern half, by Indians forming part of the Yuman linguistic stock. In 1902 appeared Dr N. León's map of the Linguistic Families of Mexico in the publications of the National Museum of Mexico, in which a small area on Todos Santos bay in Lower California, a short distance south of the international boundary, is represented as belonging to the Shoshonean stock. 
This area on the map is apparently intended to designate the general location of a Shoshonean group rather than to define its exact geographical limits. In the same year the same author published in the Annals of the Museo Nacional of Mexico (vir, 263), an article under the title "Los Comanches y el dialecto Cahuillo de la Baja California." The second part of this contribution consists of a Cahuilla vocabulary communicated to the author in manuscript by $A$. Peñafiel. It is stated that according to the census of 1895 there were $55^{8}$ "Cahuillos" in " Ensenada and Todos Santos." The Peñafiel vocabulary is compared by Dr León with a Cahuilla vocabulary from Latham's Comparative Philology, originally from Whipple, and it is found that " great and radical differences between them become apparent, to such a degree that they appear to be of diverse origin. There seems to be a marked Nahua influence in the one from Lower California."

The reason for this difference is easily discovered. Latham's vocabulary, like those of Loew, Boas, and others, which are all from within the United States, is Cahuilla, that is, Shoshonean ; the Peñafiel " $\mathrm{Ca}$ huillo" vocabulary from Lower California, however, is Yuman. This is not only certain, but in entire accord with the unvarying statements of travelers and investigators to the effect that the Indians of the northernmost part of Lower California are closely related to the Diegueno of southernmost Upper California, and therefore Yuman. It is accordingly apparent that the term Cahuilla, also written Coahuilla, Kawia, Kauvuya, etc., which has ordinarily and properly been used of the Shoshonean Indians who inhabit the region between the San Jacinto and San Bernardino ranges in southern California and who are most nearly related in dialect to the Agua Caliente, Luiseño, and San Juan Capistrano Indians of the coast region to the west of themselves, has somehow also come to be a designation, how commonly is not known, of the northermost Yuman Indians of Lower California.

In $1903 \mathrm{Mr} \mathrm{C}$. H. Marks Jr accompanied a biological expedition of the California Academy of Sciences from San Francisco to the Revillagigedo islands. During a one day's stay of the expedition at Ensenada, the settlement on Todos Santos bay, Mr Marks met and overcame various difficulties that arose and succeeded in obtaining and verifying a vocabulary of the Indians of the region. This vocabulary completely corroborates the "Cahuillo" one of Dr León in being Yuman, as appears from the following selected words:

One, cin; two, uwá; three, umóx; four, cipáp; five, särä'p; eye, yiu ; nose, hu; ear, cimä'tl; tongue, nipättl; mouth, ax; fire, ahaúu; wood, $i$; earth mût; rock, wix; water, $x a$; drink, si. 
It is accordingly plain that the supposed Shoshonean territory in northern Lower California does not exist, and that all the northern half of the peninsula was, as has heretofore been believed, an unbroken area of Yuman territory.

A. L. KRoEber.

Ponce de Leon and the "Fountain of Youth." - On reading in the last number of the Anthropologist (pp. 368 A, B) an abstract of Mr James Mooney's paper on the "Ethnography of Florida," I am reminded of the fact that, some years ago, while making some historical and philological investigations, it became of interest to me to know the meaning of the word bimini, which the Spaniards of Boriken (Porto Rico), Juan Poncé de Leon among the number, understood from the Arawaks to be the name of an island which lay far out at sea to the northwest; which was extremely rich in gold; and on which there existed a spring of which the water possessed the miraculous property of renewing the youth and restoring the vigor of any aged person who drank of it or bathed in it. It was with the object in view of discovering, subjugating, exploring, and settling this island of Bimini, and of taking advantage of the restorative power of its marvelous spring, that Ponce, enervated by the "strenuous" life that he had led, set sail from the port of San German, March 3, $15^{1} 3$, on an expedition in which, although he failed to find Bimini, he discovered what he supposed to be an island, to which he applied the name of Florida.

It appears from history that the existence of a vigor-restoring spring on some far-away island of uncertain location had long been a tradition current among the Arawaks, and that some of these Indians had, as $\mathrm{Mr}$ Mooney states, reached the mainland in their efforts to find it, long anterior to the time of Ponce. Failing, in my researches, to ascertain that any explanation of the meaning of the name of this mythic island had ever been given, I finally consulted an Arawak vocabulary in von Martius' Beiträge zur Ethnographie... Amerikas (II, p. 319), and, from the elements of the word which I found therein ( $b i$, 'life'; mini, 'fountain,' 'spring,' 'source '), discovered its signification to be 'fountain of life.' According to the metaphorical system of nomenclature in vogue among both the Arawaks and Caribs, the name of the spring may have been applied to the supposed island on which it was believed to exist. Bimini is now the name of a group of small islands lying at the northwest extremity of the Grand Bahama Bank and east of the Gulf stream. A large island named "Illa de Beimeni parte" appears on a map in Peter Martyr's Decades, published in 15 I $\mathrm{I}$. 
The phrase, "Fountain of Youth," with which we are so familiar in connection with the name of Ponce de León and his discovery of Florida, is doubtless a translation of the phrase used by old Spanish writers, and this again may originally have been a free translation of the Arawak word, although I have met with no statement by the Spanish historians that would seem to give countenance to such a supposition.

W. R. Gerard.

Recent Folk-lore Meetings in California. - The first regular meeting of the Berkeley Folk-Lore Club, founded May 3, 1905, was held in the evening of August 18 at the University of California. The committee appointed to draft an organization reported as follows:

The committee appointed May 3, 1905, by unanimous vote of the charter members of the Berkeley Folk-Lore Club to report on a scheme of organization for the Club, beg leave to submit the following:

\section{Constitution of the Berkeley Folk-Lore Club}

1. This Society shall be called the Berkeley Folk-Lore Club.

2. Besides the fifteen charter members, to wit: Messrs Lange, Mitchell, Goddard, Dresslar, Hart, Setchell, Merriam, Richardson, Fryer, Gayley, Miller, Ritter, Keeler, Noyes, and Kroeber, members shall consist of such men members of the Academic Senate of the University of California, and such men members in good standing of the American Folk-Lore Society, as are unanimously elected by the Club; and of such only.

3. The officers shall be a President, Vice-president, and Secretary, who shall constitute an Executive Committee which shall arrange for all meetings and transact all business of the Club.

4. Four or more meetings annually shall be held, at the first of which in each academic year the officers shall be elected.

5. Five shall constitute a quorum for the transaction of business.

6. Amendments to this constitution may be proposed at any meeting of the Club and adopted by a two-thirds vote of those present at the next meeting.

The Committee recommend the adoption of this constitution and the immediate organization of the Club under its provisions.

$$
\text { Signed : }\left\{\begin{array}{l}
\text { A. L. Kroeber } \\
\text { ChArLES KeELER } \\
\text { G. R. Noyes }
\end{array}\right.
$$

The report of the Committee was discussed and accepted, the proposed constitution being thereby adopted.

The following officers were then elected: President, A. F. Lange; Vice-president, Charles Keeler; Secretary, A. L. Kroeber. New mem- 
bers elected were: Prof F. W. Putnam, Dr B. P. Kurtz, and Prof H. K. Schilling.

The Committee on the establishment of a California 'Branch of the American Folk-Lore Society reported as follows :

The committee appointed May 3d, 1905, on vote of the charter members of the Berkeley Folk-Lore Club to report on the feasibility of the establishment of a California Branch of the American Folk-Lore Society, beg leave to submit the following recommendations :

That the formation of the Berkeley Folk-Lore Club provides an opportune basis for the establishment and successful development of a California Branch of the American Folk-Lore Society, which will extend the work undertaken by the Berkeley Folk-Lore Club to a wider sphere of influence and bring it before a larger body of persons, thus enhancing the promotion of folk-lore interests on the Pacific Coast. Be it resolved therefore,

That a California Branch of the American Folk-Lore Society be hereby organized by such of those present as signify their willingness; and

That a committee of five be appointed to arrange for a meeting, including a program, in Berkeley, on the evening of August 28; said committee to submit at this meeting a formal draft of organization, with nominations for officers, for the California Branch of the American Folk-Lore Society.

$$
\text { Signed: }\left\{\begin{array}{l}
\text { A. L. KroEber } \\
\text { Charles KeELER } \\
\text { G. R. NOYes }
\end{array}\right.
$$

This report was adopted, and the following committee appointed under its provisions to report at the first meeting of the California Branch on August $28:$ J. C. Merriam, G. R. Noyes, A. L. Kroeber, W. C. Mitchell, and Charles Keeler.

The work of the California Branch of the American Folk-Lore Society is designed to be directed to the study of the many elements of folk-lore existing in California among its Indian, Spanish, American, and Asiatic populations, and to the awakening of interest in such studies, by the institution of public lectures, meetings devoted to discussions and comparisons, systematic researches leading to the publication of new information, and the ultimate formation of branch or affiliated societies in various parts of the Pacific Coast. The work that is thus planned is connected so intimately with the history of California, and will be so illustrative in a wider sense of the development of the state, that the furtherance of this work should be of general interest.

The first regular meeting of the California Branch was held August 28 in the Philosophy Building, at the University of California, Berkeley. Dr C. Hart Merriam of Washington City gave the address of the even- 
ing on "Aboriginal Folk-lore from California." Prof F. W. Putnam, president of the Boston Branch, Dr Roland B. Dixon, president of the Cambridge Branch, Dr Charles Peabody of Cambridge, and Professors J. C. Merriam and W. E. Ritter of the University of California spoke on the aims and possibilities of the Branch and the development of folk-lore studies in California. A second meeting was held in Berkeley August $3 \mathrm{I}$ in conjunction with the American Anthropological Association.

At present meetings will be held chiefly in Berkeley and San Francisco, but it is hoped that before long it will be possible to meet also in other cities in California and adjoining states.

Muskwaki Indians of Iowa. - Dr Duren J. H. Ward of Iowa City has recently spent eight weeks in the study of the Muskwaki, or Fox, Indians near Tama, Iowa, in the interest of the State Historical Society. These and the Sauk, or Sauki, Indians have been so long and intimately associated that their separate tribal identity has been lost for generations. While their dealings with the Government have nearly always been as Sauk and Foxes, yet most of these $35^{\circ}$ Indians in Iowa are said to regard themselves as Muskwaki. With the exception of half a dozen Winnebago these people are descendants of those who in 1846 were forced to move to Kansas after ceding to the United States all their lands west of the Mississippi in 1842 ; but small bands wandered back to their old home, and on petition of five hundred citizens, between $185^{2}$ and 1854, were permitted to remain. About the winter of $1856-57$ the band that had settled at Tama purchased eighty acres of land for $\$ 1,000$, and from that date to $\mathrm{x} 886$ the tract had increased by purchase to about $I, 500$ acres, the Indian title to which was confirmed by act of Congress of October I, 1886 ; and by 1899 additional purchases increased their holdings to about 3,000 acres, at a total cost of $\$ 85,635$. To the section occupied by these Indians Dr Ward suggests that the name "Musquakia" be applied. What may be regarded as the most interesting discovery made by Dr Ward is a fragmentary history of the tribe, written by Chakatakase. With the understanding that it shall not be translated, the manuscript has been transferred to the State Historical Society for publication in the Muskwaki language, the Indians to receive three hundred copies of the printed work, which will make about fifty pages. A model of a Muskwaki house, $3^{6}$ by 28 by 22 inches in size, has been deposited among the collections of the Historical Society.

Inlaid Objects : A Correction. - In an article on "Ceremonial Objects and Ornaments from Pueblo Bonito," published in the last number 
of the American Anthropologist, Mr George H. Pepper thus misquotes (p. I97) my account of the mosaic frog from Chaves Pass, Arizona: "As an example of mosaic work, this object is the only veritable mosaic known to me from ruins in the Southwest." What I did publish (Smithsonian Report for 1896 , pp. 529-530) is as follows: "As an example of mosaic work this object is unsurpassed and with the exception of one other is the only veritable mosaic frog known to me from ruins in the Southwest." I have here italicized the words that Mr Pepper has omitted in his version. There are several ancient Pueblo mosaic objects in the National Museum, collected, figured, and described by me.

J. WALTER FEWKES.

The So-called " Oldest House " in Santa Fé. - In the city of Santa Fé, New Mexico, opposite the chapel of San Miguel, there stands an adobe house that is locally reputed to have been the oldest house in this next to the oldest permanent settlement made by Europeans within the limits of the United States, and also to have been the last remnant of the ancient Indian pueblo of Analco. In January, 1902, I had the good fortune to be present during the repairing of this old structure and of having the opportunity of thoroughly examining the walls as they were reconstructed. These were found to consist of (I) numerous fragments of recent Mexican adobe work, the result of occasional repairs; (2) large portions, perhaps three-fourths of the entire structure, of old Mexican adobe masonry contemporaneous with the major part of San Miguel chapel, and (3) in three places, forming the foundation and at no point exceeding 18 inches in height, considerable fragments of the original pueblo wall, the adobe masses exactly corresponding, in texture, dimensions, and mode of construction, with those in the remaining walls of the pueblo of Kwapoge on the hill formerly occupied by Old Fort Marcy, at the northern edge of the town. The results of this examination are thus in accord with the belief of $\mathrm{Mr}$ Bandelier, expressed years ago, that this so-called "oldest house" belongs mainly to the historical period.

EDGar L. HewetT.

E1 Morro Inscriptions. - The latest contribution to the literature of the historically important inscriptions made by early Spanish explorers and missionaries on the face of El Morro, or "Inscription Rock," a sandstone mesa about 35 miles east of Zuni pueblo, New Mexico, appears in vol. I, no. I, of the Proceedings of the Delaware County Institute of Science (Media, Pa., I905), under the title "Photographs of Some of 
the Inscriptions on El Morro, New Mexico." The illustrations consist of ten excellent half-tone reproductions of photographs made by $\mathrm{Mr}$ Homer E. Hoopes, and are accompanied by transcriptions and annotated translations by Mr Henry L. Broomall, who corrects some of the translations made by previous writers on the subject. The Spanish inscriptions on $\mathrm{El}$ Morro are interesting from both a historical and an ethnologic point of view, as they furnish tally dates and other information respecting some of the most important visits by the Spaniards to the western Pueblo tribes in the seventeenth and eighteenth centuries. All of the inscriptions are not included in the present treatise, but it is hoped that the remainder will be similarly photographed and translated in a future publication.

The Mrssouri Historical Society has adopted a resolution requesting its president, Dr C. A. Peterson, to prepare a form of declaration of trust whereby the Society can vest the beneficial ownership of all the property owned by it in the people of the state of Missouri, to be subject to the control of the Society as heretofore. By transferring its building and other property to the State, it is believed a greater degree of safety for the records and collections will be insured, while the Society will become more permanent in character. Among its possessions is a valuable archeological collection, recently enriched with some of the objects recently found by Mr David I. Bushnell Sr in his excavation of the N. D. McEver's mound in Pike county, Illinois.

DR George Grant MacCurdy of Yale University has been elected to honorary membership in the Missouri Historical Society. He has also been chosen to represent the Ecole d'Anthropologie de Paris at the forthcoming inauguration of Dr Edmund J. James as president of the University of Illinois.

The British government has granted a pension of $£^{200}$ to Dr J. G. Frazer in recognition of his literary merits and of his anthropological studies, and a pension of $£^{\mathrm{I}} 50$ to the Rev. Lorimer Fison in appreciation of the originality and importance of his researches in Australian and Fijian ethnology.

The meeting of the American Anthropological Association held in San Francisco, August 29-31, was successful in every way. The proceedings of the meeting and several of the important papers that were read will be published in the next issue of the American Anthropologist.

The government of Ontario has planned to publish a Handbook of Canadian Ethnology and Archeology for the benefit of the Fifteenth 
International Congress of Americanists to be held at Quebec in September, I 906 .

The sixth Congress of Criminal Anthropology will meet at Turin on April 28, 1906, under the presidency of Professor Lombroso. An exhibition of criminal anthropology will be held in connection with the congress.

The Sauk County Historical Society has been organized in Wisconsin, to further archeological and historical research, by Messrs A. B. Stout and H. E. Cole, members of the Wisconsin Archeological Society.

DR W J MCGEE, who has devoted the last two years to the Department of Anthropology of the Louisiana Purchase Exposition, has been appointed managing director of the new Saint Louis Public Kuuseum.

The University of Pennsylvania will receive $\$ 60,000$ from the estate of the late Professor Maxwell Sommerville, who held a chair of archeology in the university.

The BERLIN MUNICIPALITY has appropriated $\$ 20,000$ to erect a statue in honor of Rudolf Virchow, which will be placed on the Karlsplatz, close to the Charity Hospital.

Prof G. F. Wright, of Oberlin College, is making a trip to southern Russia and the Red sea to continue his geological and anthropological studies in that region.

THE fourth meeting of the German and Vienna Anthropological Society was held at Saltzburg on the 28th to the 3 oth of August.

Clark Wissler, Ph.D., and Berthold Laufer, Ph.D., have been appointed lecturers in anthropology at Columbia University. 